\title{
Halalbihalal Tradition in Java 2010-2015
}

\author{
M. Ma'ruf Misbah \\ Fakultas Adab dan Humaniora \\ UIN Syarif Hidayatullah Jakarta \\ Jl.Ir. H. Juanda No.95 Ciputat, Indonesia \\ mm.misbah@uinjkt.ac.id
}

\begin{abstract}
This article discusses the halalbihalal tradition among Javanese Muslims that was held only at the time of Eid al-Fitr, whereas the behavior of mutual forgiveness and kinship (silaturahmi) which became the character of the tradition, could be done at any time. This research aimed at finding out of the cultural power behind halalbihalal tradition among Muslims in Java, Indonesia that was held every year after Eid al-Fitr between the years 2010-2015. To reach the goal, the writer did an analysis with qualitative research method and using religious and anthropological approach. This approach was used because halalbihalal had relation to religion aspect and human behavior which was the subject of the tradition. The result of this research showed that there were two factors constructing the cultural power. Those two factors were religion and anthropology factor. From the results of research, there was a religious view among Muslims that they had an obligation to apologize to others for their speech or deeds that might have to disturb other's feelings. In addition, there were also anthropological phenomena that shaped human behavior in halalbihalal activities so that it became a tradition. In conclusion, there was a cultural power behind the halalbihalal tradition which was the root of the strengthening of the tradition. The atmosphere of Eid al-Fitr which came after fasting in Ramadan month, was the most appropriate moment for halalbihalal activities. The behavior of mutual forgiveness and kinship in halalbihalal tradition could complement the worship that had been done in the Ramadan month. The impact was that the halalbihalal activity could be carried out every year after Eid al-Fitr and the form of activities also varied.
\end{abstract}

Keywords - Eid al-Fitr; halalbihalal tradition; cultural power.

\section{INTRODUCTION}

Halalbihalal is a part of various forms of Islamic civilization found in Java, Indonesia. The form of this civilization is an activity to apologize each other and to forgive for any deeds and speech that might disturb other's feelings, which may have been done, in a group of people, in which the civilization was related to Eid al-Fitr, the feast of the Muslims.[1] The arrival of Eid alFitr was related to the end of fasting in Ramadan, the holy month of the Hijri calendar. In submitting the apology, they usually accompany it by shaking hands.[2]

For the Javanese people, the halalbihalal activity was very common because it was easily found in various places and areas along with the coming of the feast of Eid al-Fitr. The activity was a typical Indonesian tradition.[3] The tradition was highly developed in Java. In the period between years 2010-2015, the development appeared to be increasing.[4] By its characteristic, halalbihalal became a tradition with its uniqueness. Many people wrote that there were discussions related to the halalbihalal tradition, although the tradition was not a central topic of writing. In addition, there were also writings that discussed halalbihalal, but in relation to the history of Islamization in Java.[5]

This article certainly had its uniqueness and distinction, because it elevated "cultural power" as the core of its discussion. The main objective was to investigate the cultural power behind the halalbihalal tradition and the factors that supported it. This was the uniqueness of the article when being compared to other literature that has been surveyed.

\section{METHOD}

This research was conducted by using qualitative research method through two approaches, namely religious and anthropological approach. The use of a religious approach, of course, based on the phenomenon that the halalbihalal tradition wa something to do with Eid al-Fitr, the feast of the Muslims. There was also religious advice for them to apologize each other and to forgive for any behaviors which might disturb the feelings and may have done in friendship relation, brotherhood, and other. On the other hand, an anthropological approach was also used. This was due to the existence of fact that the halalbihalal tradition was related to the human behavior that has shaped a tradition in their lives. There was a tradition that has made halalbihalal as a very important moment for apologizing and forgiving among halalbihalal participants and for establishing kinship and friendship.[6] Their behavior has also succeeded in strengthening halalbihalal as a tradition.

Their ways of expressing ideas in the form of behaviors could be discussed in anthropological perspectives. Their behavior in implementing halalbihalal could be understood as their ordinance in expressing ideas to build kinship, brotherhood, and friendship relations in harmony. They do halalbihalal every year. Therefore, halalbihalal activities became a tradition for them. Through halalbihalal activities, they have established a system in strengthening kinship, brotherhood, and friendship. Because the goal was noble, their ordinances in achieving the goal which expressed in the form of halalbihalal activity became very important. 


\section{RESULT AND DISCUSSION}

\section{A. RESUlT}

The essence of halalbihalal activity was the apologies to each other and forgiving among the participants of the tradition over any remarks or deeds that may disturb the feelings.[7] The halalbihalal tradition could be carried out in several different forms, but the core purpose was the same. There were several forms of halalbihalal activities. There was halalbihalal which done by individual Muslims spontaneously to other people he met during the Eid al-Fitr. This activity could be done after the Eid al-Fitr prayer. They could carry out the tradition to others known and encountered at the site of the Eid al-Fitr prayer, in the journey from the site, or on another opportunity that happened spontaneously and individually. Individual and spontaneous Halalbihalal to the people he met could also be done among group members, who had the same profession. A student, for example, could do halalbihalal with other students in his school, as well as people who had other professions.

There was also halalbihalal that was done by visiting the family members to apologize and forgive each other. Usually, a tradition was carried out by family members of a younger age than the family members visited. A family members who lived in areas far from their parents would travel to meet another family members from the offspring of his parents. It has contributed to the increase of transportation flows, especially from big cities to various regions, some days around Eid alFitr[2, p. 1099], [7, p. 177]. Halalbihalal among family members could also be done by inviting all family members in a family gathering to attend the halalbihalal meeting. That family gathering commonly used the term "Bani" (descendant) which was associated with the name of the parent of the family. For each member of the gathering, that parent may be on the father, grandfather or great-grandmother position in the family genealogy [9, p. 86]. This halalbihalal meeting, in addition to being filled with the expression to apologize for each other and forgive, was also commonly filled with speeches to convey good advice which often referred to as mauidhah hasanah [8, p. 214], [9, p. 339]. In addition to visiting family, halalbihalal could also be done by visiting friends or in alumni meeting from an educational institution that was held in Eid alFitr[2, p. 1099], [8, p. 112].

The results of the research showed that the continuity of halalbihalal tradition could be used as an indicator of existence the cultural power behind the tradition. It showed that halalbihalal activity had a very close relationship with the feast of Eid al-Fitr. This tradition was carried out as a filler of Eid alFitr atmosphere[2, p. 1099]. There was a comprehensible explanation of the time of halalbihalal activity in the atmosphere of Eid al-Fitr after the completion of Ramadan fasting. The cultural power behind halalbihalal has become a solid root for the growth of the tradition. The cultural power became a mover of human behavior to carry out halalbihalal every year. The cultural power behind the halalbihalal tradition in the atmosphere of Eid al-Fitr was built by the existence of two elements, namely religious and anthropological elements. This cultural power became the core of research, so the discussion in this article had a uniqueness which was not found in other articles that have been surveyed. This was very interesting to discuss further.

\section{B. DISCUSSION}

There was a series of activities in sequential between the three things among Javanese Muslims that occured in Ramadan and Shawwal (a ninth and tenth month in the Hijri calendar). The series of activities began with fasting activities in Ramadan, Eid al-Fitr on 1 Syawal, and then halalbiihalal which was generally in Shawwal. In Ramadan, all Muslims who have been mukallaf were obliged to perform fasting[10, p. 261], [10, p. 261]. In this month, Muslims were also strongly recommended to do the activities of sunnah, such as reading the al-Qur'an (tadarus), and perform pray tarawih, witir, and tahajjud, and other sunnah activities[11], [13, p. 102, 105, and 211], [12]. The various activities had a direct connection to God, and therefore, could be categorized as an activity of habl min Allah, "vertical link to Allah". In addition to these activities, Muslims were also obliged to keep the tongue by good speaking. The words and deeds were not allowed to hurt other people's feelings[13]. Of course, there were still many other good activities that were recommended to be do by Muslims in the month of Ramadan. Various forms of good deeds associated with humans could be categorized in the activity of habl $\min$ al-nâs, horizontal connections with other humans.

The first of Syawal is the date of the coming of the feast of Eid al-Fitr. Etymologically, Eid al-Fitr is a group of words derived from Arabic. From the morphological aspect, according to Manzûr[11], the word "eid" comes from the word " $a$ - $d a$ " meaning "back" and has a connotation to events that come back each year. This is also in accordance with the explanation in the book of fiqh that the word "eid" is derived from the word "ûd", which meaning back, because the event of Eid al-Fitr is coming back in every year, where the joy and happiness comes back in that day[13]. Furthermore, the word "al-Fitr" if associated with the topic of fasting, means "aftara"or "iftâr" meaning "eat and drink", "fasting couldcellation", not fasting condition[14, p. 1253], [15, p. 1389]. Therefore, in the relation with fasting in Ramadan, the word "Eid al-Fitr" could be interpreted as "back not fasting". On the feast of Eid al-Fitr on the first of Syawal, Muslims are not allowed to fast[13, p. 215], [15, p. 298].

The arrival of Eid al-Fitr was followed by the emergence of halalbihalal tradition. The activity of mutual apology and forgiveness among halalbihalal participants included the activities of habl min al-nâs category. Thus, halalbihalal activity could complement activity in the month of fasting, especially the activities included in that category. When performing fasting in Ramadan, the Muslims, as mentioned above, should not say and do anything that could harm other people's feelings. Speech and deeds that could harm others are very bad deeds[15, pp. 297298]. At the time of halalbihalal, they apologize and forgive each other if there are words and deeds that have disturbed their feelings. On the other hand, the activity of mutual forgiveness is usually accompanied by the hope that their fasting in Ramadan is accepted by Allah.

The linkage of halalbihalal tradition with the feast of Eid alFitr is a root sturdy for the continuity of the implementation of that tradition. The existence of religious elements that have motivated the implementation of halalbihalal is a factor that has grown the cultural power that is behind that tradition. At least, there are two religious elements behind halalbihalal, that is the element of silaturahmi (kinship) and the element of "mutual apology and forgive". Both elements are akhlak or behavior that is commendable. The commendable akhlak is called al-akhlâq al 
-mahmûdah[16, p. 204]. In Islam, the formation of al- akhlâq almahmûdah includes priority.

The silaturahmi is "an effort to strengthen brotherhood, kinship, and friendship"[3, p. 1306]. Muslims not be allowed disconnect the ropes of silaturahmi. Therefore, halalbihalal used as an effort to strengthen that rope. Muslims find a very precise moment in the halalbihalal tradition to conduct the silaturahmi. Therefore, they always attempted to preserve that tradition. In addition to "silaturahmi", there is an element of "mutual apology and forgive" that has motivated the implementation of halalbihalal tradition. This phenomenon is also a sturdy root in growing "cultural power" behind the implementation of halalbihalal. "Apologize and forgive" are two things needed by Muslims in an effort to wipe out the sins caused by actions or utterances that disturb the feelings of others, which he may have done. Thus, the stronger the good relation between each individual from halalbihalal participants. Halalbihalal is used as the right momentum to apologize and forgive each other[7, p. 177].

In addition to religious elements, there are also anthropological elements that helped build the cultural power behind the implementation of halalbihalal. It could be analyzed in the study of cultural anthropology which was a part of anthropology[17, p. 23]. The way of expressing the core purpose of halalbihalal in some form as described above has been used in carrying out the tradition. From the cultural anthropology aspect, halalbihalal was needed to preserve the noble tradition, which in there was an effort to strengthen the "silaturahmi" and the attitude of "apologize and forgive each other". Their need to build a noble tradition of arranging the good relationships between individuals in life was also a sturdy root and could grow the cultural power behind halalbihalal activity. There was local wisdom in building the cultural power behind the activity[18, p. 33].

In the context of halalbihalal for Paguyuban Bani (posterity group) that associated with the name of the parent of the family, there was an anthropological element that helped foster "cultural power" behind that tradition. From the name of the parent of the family, each member of Paguyuban Bani was in a different position in the genealogy of the family. The term "Bani" was often used for a large family with many members. Therefore, family members in Paguyuban Bani could sometimes come from four generations, that was the generation of "children", "grandchildren", "great- grandchildren" and "piut", child of great -grandchildren. Piut is the fifth generation in the family genealogy[3, p. 1083]. In such circumstances, the parent of the family, which was the name of the gathering, has reached a position above the great-grandmother. For the family members of the Paguyuban Bani, halalbihalal was of course indispensable, in addition to "silaturahmi" and activities of mutual apologize and forgive, also to be familiar the members of the family, especially for those who rarely meet each other. Halalbihalal could be used as a means of preservation of the introduction of trah members, "descendants in the Paguyuban Bani"[11, pp. 338-339].

\section{CONCLUSION}

The conclusion of this article is that halalbihalal had very strong roots and was able to grow into a tradition that was always carried out every year along with the coming of the feast of Eid al-Fitr. The tradition was related to the religious aspect and cultural-anthropology. From the religious aspect, there were elements of "silaturahmi" and activity of "mutual apology and forgive" that motivate halalbihalal activity[8, pp. 112-112], [10, p. 214]. This phenomenon was very appropriate with the nuances and spirit of Eid al-Fitr after carring out the fasting in Ramadan. Therefore, halalbihalal activity was carried out in the time of Eid al-Fitr. Both elements from that religious aspect became a mover for cultural power behind the halalbihalal tradition among Muslims.

Furthermore, from the cultural-anthropology aspect, there were various halalbihalal activities that were used by them as a means to carry out "silaturahmi" and "mutual apologize and forgive" activities. In the context of halalbihalal among members of Paguyuban Bani, there was an element of trah meeting -- Bani members meeting --, so that they always knew their members and knew the genealogy of the big family in the Paguyuban Bani[8, p. 112], [11, p. 339].

\section{REFERENCES}

[1] Fathurrahman, B. B. Wiyono, I. Bafadal, dan I. Arifin, "The Professional Teachers in International Conference on Education, Malang, 2016, pp. 265--272.," dipresentasikan pada International Conference on Education, Malang, 2016, hlm. 265-272.

[2] Bahrudin, "Prinsip-Prinsip Komunikasi dalam Hadits Nabi," J. Ilmu Dakwah, vol. 4, no. 11, hlm. 1093-1116, 2008.

[3] Tim Redaksi, Kamus Besar Bahasa Indonesia. Jakarta: Gramedia Pustaka Utama, 2008.

[4] K. Muh, D. A. Arubusman, dan D. D. Kania, "Manajemen Angkutan Lebaran Terpadu," J. Manaj. Transp. Dan Logist., vol. 1, no. 2, hlm. 103-115, 2014.

[5] H. Saiful, "Halal Bi Halal, A Festival of Idul Fitri and It's Relation with the History of Islamization in Java," Episteme, vol. 10, no. 2, hlm. 385-403, 2015.

[6] H. Sigit, Djatmika, Wakit, dan D. Purnanto, "Pattern and Meaning of the Ujung Culture (An Ethnolinguistic Study in Kartasura, Sukoharjo Regency," Pros. Prasasti, hlm. 695-704, 2016.

[7] B. Rudy dan I. Hamsinah, "Aspek Keseimbangan Pasar pada Fenomena Kenaikan Tiket Angkutan Umum Kereta Api pada Masa Lebaran Tahun 2009," J. Ekon. Dan Bisnis, vol. 3, no. 3, hlm. 175-185, 2009.

[8] R. Aang, "Ragam Khitobah Ta'tsiriyah; Sebuah Telaah Ontologis," J. Ilmu Dakwah, vol. 5, no. 17, hlm. 197-232, 2011.

[9] T. Atik, "Gaya Pengelolaan dan Dinamika Trah Jawavol," Humaniora, vol. 21, no. 3, hlm. 338-349, 2009.

[10] al-Malîbâri, Fath al-Muîn Bi Syarh Qurrah al-Ain Bi Muhimmât alDîn. Beirut: Dâr Ibn Hazm, 2004.

[11] Ibn Manzûr dan Jamal al-Dîn Muhammad, Lisân al-'Arab, Beirut, , (1990). [8] Abu al Khasyâb. Beirut: Dâr al-Fikr, 1990.

[12] Ishâq, Abû, al-Muhadzdzab Fî Fiqh al-Imâm al-Syâfii, vol. 1. Beirut: Dâr al-Ma'rifah, 1959.

[13] al-Husaini, Kifâyah al-Akhyâr Fî Halli Ghâyah al-Ikhtisâr. Beirut: Dâr al-Minhâj, 2008.

[14] al-Fairûzâbâdi, “al-Qâmûs al-Muhît.” Dâr al-Hadîts, Kairo, 2009.

[15] A. Atabik dan A. Z. Muhdlor, "Kamus Kontemporer ArabIndonesia.” Yayasan Ali Maksum, Yogyakarta, 1996.

[16] A. As, Pengantar Studi Akhlak. Jakarta: PT. RajaGrafindo Persada, 1994.

[17] Koentjaraningrat, Pengantar Ilmu Antropologi. Jakarta: Aksara Baru, 1980.

[18] H. Taufik, Muhamad, "Antropologi Islam di Indonesia," J. Kebud. Islam, vol. 11, no. 1, hlm. 31-45, 2013. 